\title{
ANALYZING SOME PROBLEMS CAUSED BY NEGLECTING CITIZEN'S PARTICIPATION IN FORMULATING LOCAL GOVERNMENT REGULATION
}

\author{
Novita Dian, SH. MH. \\ Prof. Dr. Gunarto H., SH., S.E.Akt., M.Hum. \\ Dr. Mashdurohatun Hj. Anis, S.H., M.Hum.
}

\begin{abstract}
Government usually has some spesific goals in arranging a work-plan, that are to improve people's prosperity level and also to create justice among them. Because the work-plan concerns on the citizens, They are supposed to give their participation in the formulation of work-plan draft. Based on that reason, it is needed to analyze some problems caused by neglecting citizen's participation in formulating local goverment regulation. Constructive paradigm was used in this research. It is often used in philosophical tradition as a method of reading the text and its empirical reality. The design of this research was legal research which concerned on analyzing social-legal problems. In collecting the data, social-legal approach, qualitative approach and field-note were used in this research. Based on the result of this research, the researcher found that it was important to make a rule in the process of formulating regional regulation. The regulations need citizen's active participation. If there were no participation, It would rise some problems, such as juridical problems, structural problems, and cultural problems. Those problems would make invalid or null and void regulations. Therefore, the citizens are expected to control the implementation of regional regulation by giving some suggestions and critics to minimize those problems above.
\end{abstract}

\section{KEY WORDS}

Citizen's participation, local government, regulation, public service.

Indonesia is a State based on the rule of law. Therefore, every policy and work-plan made by the government should be based on law. There is a Juridical strenght about citizen's involvement in the process of arranging those laws. It is based on The Constitution of the Republic of Indonesia of 1945 Article 1 about sovereignty as follows:

(1) The State of Indonesia shall be a unitary state, with the form of a Republic;

(2) Sovereignty is vested in the people and implemented pursuant to the Constitution;

(3) The State of Indonesia is a state based on the rule of law.

As stated above that sovereignty is vested in the people, means that people's power in law will be more meaningful if they were involved in arranging that law from the planning step up to its implementation. Although there is the People's Representative Council, it is better that people should be involved directly in the process of formulating regional regulation.

Indonesia is a democratic country. A prominent feature of democracy is govermentor the people, by the people, and for the people. Hence, people have significant rule in government administration. This statement is in line with The Constitution of the Republic of Indonesia of 1945 Article 1 Section 2 that Sovereignty is vested in the people and implemented pursuant to the Constitution. People's involvement related to regulation arrangement is also mentioned in Act Article 96 Number 12 of 2011, Presidential Regulation Number 87 of 2014 about legislation's formation, and Government Regulation Number 45 of 2017 about citizen's involvement in local government administration

\section{METHODS OF RESEARCH}

Contructivist paradigm was used in this research. Philosophical system often used this paradigm as a reading method of one context and as a tool to show the fact empirically. Furthermore, the researcher used ontology approach to discuss the existence of one case in concrete way. It was expected that this research would give a real condition happened in 
society if there was regulation formulated by representative council and local government as the holder of its regulation. With the result that it would be known the rule on how the regulation being formulated. In this research discussion, Relativism theory was needed to show the differences of societies' expectation and the main goal of the local regulation. Although the goal took side with society, but sometimes there was some factors affected on the implementation.

The researcher used some theories as references to gain new findings of societies' participation in formulating local government regulation. In this research, both Pragmatic Theory and Epistemology Theory were used as references although those theories concerned on differences goal. Pragmatic studies often seek to understand the multiple factors involved in people's actions in a given situation while epistemology is concerned with possibilities, nature, sources and limitations of knowledge. In simply words, epistemology focuses on what is known to be true. So this research tend to use epistemology theory because the main problem wanted to be researched was a formulation process of local government regulation which involved citizen's participation to realize their hopes.

The researcher's expectation on the reseach methodology was in line with the objective of this study. It was about local government regulation that should be formulated to make society more properous. Therefore, it should be made its juridical foundation that in line with law-enforcement theory. But, if the theory was not agreed with the real condition, the third theory, progressive-law theory should be choosen to harmonize what had been written in the regulation and the real societies' expecatation.

The design of this research was legal research which concerned on analyzing sociallegal problems. In collecting the data, social-legal approach, qualitative approach and fieldnote were used in this research. Social-Legal research known as a research that concerned on Norm Jurisprudence but it did not examine the norm but to examine the result or people's reaction if the norm had been applied in the society.

This is a qualitative research that examines about society's behaviour in group or individually, society's principles, society's understanding, and society's assumption. ${ }^{1}$

Soetandyo Wignjosoebroto mentioned that sociological and juridical legal research is grouped into doctrinal legal research of in concreto type and normative legal research of in abstracto type. ${ }^{2}$

In collecting data, the researcher only focused on the main problem that would be solved so there would not be over discussion. There were some sources used by the researcher as follows:

Primary Sources of Data. Because this research wanted to anayze some problems caused by neglecting citizen's participation in formulating local goverment regulation, so their participation was considered as primary sources of data.

Direct observation and interview was conducted because the reseacher wanted to get real information from society, not only about social fact but also he/she wanted to know the reason why that case happpened.

Secondary Sources of Data. The researcher used secondary sources of data as a supplement of primary data. They would be useful for the researcher in analyzing primary data. Some reference books, magazines, newspapers, article and related research were used as secondary sources of data.

Tertiary Sources of Data. Dictionary of Law was used as reference to support primary and secondary sources of data.

Socio Legal Approach was used in this research. There were some steps in collecting data; Observation as primary data had been conducted to get direct information from society and from related agency. Furthermore, as supported data, the researcher also used doctrinal-law approach; Statute Approach, comparative Approach, and Conseptual Approach.

\footnotetext{
$1 \quad$ Khasan Effendy, Memadukan Metode Kuantitatif Kualitatif, Indra Prahasta, Bandung, 2010, hal.117.

2 Soetandyo Wignjosoebroto, Hukum Paradigma, Metode dan Dinamika Masalahnya, Lembaga Studi dan Advokasi Masyarakat, Jakarta, 2002, hal.147-169.
} 
In this research, a study of related documents about Law Regulation and Government Regulation was also used by the researcher to collect the data. Besides that, observation, interview and document tracking were conducted to get more detail information.

The Data was analyzed inductively and qualitatively. It's a way of analyzing descriptiveanalitic data from respondence in form of oral, written, or real behaviour in the process of formulating local government regulation which focused on their active participation. The data was analyzed by using the following approaches:

The researcher could use Law as the guidline in analyzing the data because the data wanted to be measured was about the law with the following features:

- Comprehensive, means that the legals norm related each other;

- All-Inclusive, means that the legals norm is able to solve all problems;

- Systematic, means that the legals norm is arranged orderly;

- Conceptional Approach.

The researcher used some concepts of Law as references in analyzing the data. Investigating newest legal studies helped the researcher to obtain new idea of legal meanings, legal concepts and legal principles or related problem that would be examined in this reasearch.

\section{RESULTS AND DISCUSSION}

Government has a strong authority to plan, formulate, implement, and evaluate of short term, middle term and long term development planning which oriented on citizen's need. There were some problems found in the legal's implementation from central government to legal government. There were some possibilities of those problems, as follows:

Judicial review. It is one of constitutional act that can be done of anyone who is prejudiced by the content of the law. Constitutional Court usually reviews the law if it is potentially contradicted to The Constitution of the Republic of Indonesia of 1945, while Supreme Court reviews rules that contradicted to the law. Finally their decision of Yudicial Review is considered as incrach decision.

Null and void legal regulation. It mentioned in the decision of Constitutional Court number 56/PUU-XIV/2016 and 137/PUU-XIII/2015 that Minister of Home Affairs and Governor cannot cancel local regulation, while province regulation can be cancelled by Minister of Home Affairs. Their rights is only to preview it, not to review local regulations that have been promulgated because it was made based on Constitution. Supreme Court is the only independent judicial arm of state that have rights to review it.

Because of citizen's development, there is no eternal law. That law should be revised time by time. The law is not applicable for the following reasons:

- Void ab initio of law. It can be happened if the newest law mentions that the oldest law was not valid anymore.

- The law is not applicable if the application time is too long.

- The law is not applicable because it does not fit with the development era.

Legal Void. The law is product made by society. It can be said that if there is a society, there will be a law. The existance of law tends to follow the human's movement. However the development in society to be the starting point of the existence regulation because the human's development is faster than the development of that law. The over development can make some problems. Sometimes the law does not cover all aspects of human life. Thus there are certain period when there is a legal void. It can be happen because it takes long time to formulate those regulations. The legal void will make legal uncertainty. The legal chaos in legal void period can be tolerated until there is a clear rules.

Decisions made by Supreme Court. Supreme Court is the highest independent judicial arm of the state which maintains a system of courts and sits above the other courts such as the General Court, the Religious Court, the Military Court and the State Admistration Court. In Law number 12 Article 9 section 2 of 2011 mentions that in case of a Rule under Law alleged conflict with the Law, the investigation is carried out by the Supreme Court. 
Furthermore, in Law number 4 article 11 section 2 point b of 2004 about judicial power is mentioned that the Supreme Court has the authority to review the law based on the existing regulations. It is also mentioned in law number 3 article 31A of 2009 concerning the Supreme Court.

A vacuum local regulation. A process of formulating local regulation should consider the upper regulation. In the preparation of the Privincial Prolegda as intended in Law Article 35 number 12 of 2011 about the preparation of a list of province regulation draft is based on:

- Higher instruction of Rules;

- Regional development plan;

- Implementation of regional autonomy and duty of assistance;

- Aspirations of local communities

In the process of making rules People have the right to give input orally and/or written as intendend in Law Article 96 number 12 of 2011 about public participation so the law will be applied as the people's hope. In another word, the law will be meaningless if it does not fit with their hope.

We admit that law enforcement in Indonesia from the lower to upper level is not implemented well. It caused by the goverment's rule and societies' rule. There are still many people with their lower understanding about law.

By the Enforcement of regional autonomy, the regional government has his own rights to manage his area. Central government gives him a wide chance to formulate his own rule. But in the first time of regional autonomy enforcement, there is a delegation power between Central government and Regional government. Regardless to that problem, people may have a wider chance to participate in government implementation. Their participation is really needed so every policy made based on their aspiration and their expectations.

Law enforcement according to Soerjono Soekanto is an activity to harmonize the values of law with the action to impelement it as a final goal, that is to create, preserve and maintain peaceful life. ${ }^{3}$.

Furthermore Law enforcement according to Ilhami Bisri is the effort of all elements to strengthen the nation so it become an obligation for them and it is also as a correction that the law should only be enforced by certain groups, such as:

- Some civil servants who have their own duty, such as: policemen, judge and public prosecutor whom people call the three musketers. They have different duties but their duties have a same goal, to create a fair, orderly and useful law. The police is the implementers of law enforcement in the community, a judge as a man who takes fair decisions and public prosecutor is someone who prosecutes lawbreakers;

- Lawyers have advocacy and mediation function for the community. They may work individually or who join collectively through legal aid institutions. They become a guide for those who do not know anything about law so in the judicial process, the judge's decision is based on the truth and justice so they will be treated as a human being with their honor, rights and obligations;

- Some executives which consist of civil servants with their own duties to the organizer with their political power;

- People as legal users are sometimes claimed as justice seeker. ${ }^{4}$

Although there is a perfect law but it will be meaningless if the law enforcement is still low. Law and law enforcement should be hand in hand to reach best goal or it will only be a kind of law- paper if it is not supported by a good legal system.

The main function of the law is actually as protection of human interests. To obtain that function, law should be implemented by considering the law's objective, as to create and maintain peace in life. For the shake of expected function, the law should be in line with the implementation, or in another term, law in the book must be in line with the law in action. Fuller mentioned the principles of legality as follows:

\footnotetext{
${ }^{3}$ Soerjono Soekanto, Faktor-faktor yang Mempengaruhi Penegakan Hukum, Rajawali Press, Jakarta, 2004, hal. 3.

${ }^{4}$ Ilhami Bisri, Sistem Hukum Indonesia: Prinsip-Prinsip \& Implementasi Hukum di Indonesia, Rajawali Pers, Jakarta, 2012, hal. 128
} 
1. A legal system must consist of some regulations, not only an ad hoc decision;

2. The regulations that have been made must be announced.;

3. There must not be retroactive rules. The rules cannot be used as guidelines for behavior if it is retroacive

4. The rules must be arranged in an uderstandable formulation

5. A system must not contain opposites rules

6. Rules must not contain an exceed demands

7. There should not be a habit of changing rules frequently that can make people lose its orientation

8. There must be a match between the enacted-regulations with daily implementation ${ }^{5}$.

Fuller's theory can be used as guideline in the process of formulating a law in Indonesia, especially in local regulation formulation. A rule should be formulated and applied based on certain situation and condition. Regulation is not only made without any follow-up but there should be continuity and sustainability. There should be socialization about certain regulation so it will be known by wide society.

Law- socialization should not be held afer the law has been made, but when it is still being drafted, the society must know and participate in the formulaton process. Regulation that has been made and applied are not retroactive because it will interfare the next regulation. The regional regulation should be formulated in a simple word so its message will be understood by ordinary people. A system made to avoid a conflict so there will be no more problems. Its content should also match with people's knowledge level. The law must not be over limit so the people cannot apply it well. The law is usually made for a long period unless there is an urgent condition that make a lower low should adjust to the upper law. The law must be in accordance between das solen and das sein.

Policies that regulate societies' demand in economic, political and administrative aspect will be effectively implemented if the government, the private sector and community participation are in line. In the real conditions, there are some following aspects we need to pay attention to:

- Potical Aspect. Societies do not have power to participate to in appyling the rule while they are sovereign;

- Economical aspect. Local Societies do not have chance to develop their economic level to get better life. Even though the goal of economic development is to provide job vacancy and better income;

- Social Aspect. People do not power to have healthy life and skilled health workers. They are also unable to select and be aware of the threat of integrity of the nation which connotes ethnicity and religion. Even, one of the requirement to get better life is the availabilty of educated and skilled workers;

- Cultural Aspect. Local societies are powerless in developing their culture because of the politics of standardizing culture. Even though the symbol of unity in diversity comes from the diversity of nation's culture;

- Safety Aspect. Local society is powerless from the threat of violence and disorder. Even, law and public order are the paradigms of democracy. ${ }^{6}$.

If we talk about law or regulation to ordinary people, they will confuse because they do not know exactly about it. unfortunately, they will know about certain law if they have broken it. Actually people do not need such explanation about the law, they only need a real implementation like a written rule. So in the process of formulating local regulation, their participation is needed in order that they will obey that law.

According to Soekanto, law has various meanings, namely:

- For ordinary people, especially in rural communities, law is interpreted as ceremonies according to Islam;

- In the college environment, law is generally interpreted as a rule or norm;

\footnotetext{
${ }^{5}$ http://hukum-on.blogspot.com/2012/06/asas-hukum.html

${ }^{6}$ Asosiasi IImu Politik Indonesia, desentralisasi \& otonomi daerah, LIPI Press, Jakarta, 2007, hal. 351.
} 
- Scholars argue that law is such people's behaviour in certain area and at certain times. It also known as a habit;

- According to Prod Djojodigoeno, law is a social process that comply and and validate a decision by an authorized official. ${ }^{7}$

On the other hand, Stamford said that Law is full of uncertainty (the disorder of law). But Legal certainty is forced to be believed than seeing the actual situation. ${ }^{8}$ follows:

Many things that affect the citizen's participation in formulating local regulation as

- A real social condition of societies will affect their participation in the process of formulating local regulation. They tend to be apathetic to the regulation because of their lower knowladge about it. The higher of someone's education level, the higher care they give for their environment;

- So far, people who actively participated in the process of formulating local regulation are them who called 'gentle' means that they do not ask more about the law, so the formulating process will run smoothly;

- Many people take interests in the process of formulating local regulation. One of the interests that tends to be dominant is political interest. As we know that an institution that has the authority to formulate local regulation is the legislative. The legislative members are come from different vision as mentioned in their parties so they tend to put their political interest first than the people's interest in general.

There are many rules about people's participation in formulating local regulation, such as mentioned in Law Article 196 Number 12 of 2011 about the rules of law formulation, Law Article 354 Number 23 of 2014 about regional government, Government Ordinance Article 2 Number 45 of 2017 about people's participation in local government implementation, Ministerial Decree Article 166 Number 80 of 2015 about product of regional law. In law-order, the upper regulations will be a guide for the lower regulation. But in real implemetation there sre still many regulations that the contain do not suit with the upper regulations.

The existence of law that does not apply as expected would lead to uncertainty. In reality, all people cannot accept the uncertainty thing.

But whatever the conditions is, a law must be upheld even the sky will collapse. Without the law, society will cause social chaos impact. An authoritative law is meaningless and people will againts it.

People put a great hope to government to realize a prosperity among them. In this case, the form of prosperity is very broad and tends to change according to the time. As the people's think about prosperity in pra-independence day is when our country has been free of colonial. But a different thing happened after independence day. The prosperity target is different. Along the development era, prosperity level is measured in terms of economy and safety level. Today education level become a prosperity target. Conceptually, the essence of good governance in public service as follows:

- There is an obligation for civil servants the to carry out their function and their authorities based on the principles of good governance;

- There is a recognition of citizens' rights of goverment, administrators and having good public service;

- There is a diversity of fields of public service as the result of different citizens' interest that should be met through the administration of public services. ${ }^{9}$

It becomes government's duty to realize society's expectation all the time. So that, the government should consider good governance principles. There are eleven good governance principles as mentioned by Crince Le Roy as follows:

- Principle of legal security;

- Principle of proportionality;

\footnotetext{
${ }^{7}$ Bambang Waluyo, penegakan Hukum di Indonesia, Sinar Grafika, 2016, hal 264.

${ }^{8}$ Ilham Yuli Isdiyanto, Rekonstruksi Hukum dan ketatanegaraan Indonesia, UII Press, 2017, hal 7.

${ }^{9}$ Sirajuddin, didik sukriono dan Winardi, hukum Pelayanan Publik berbasis partisipasi dan keterbukaan Informasi, setara Press ( kelompok Instrans Publishing) , Malang, 2011, hal. 11.
} 
- Principle of equality;

- Principle of carefulness;

- Principle of motivation;

- Principle of non misuse of competence;

- Principle of fair play;

- Principle of reasonableness or prohition of arbitrariness;

- Principle of meeting raised expctation;

- Principle of undoing the consequences of an annulled decision;

- Principle of protecting the personal way of life..$^{10}$

The priciples of good governance were born from the application of government administration not based on the existence of formal legal product. It should be made in line with the development era because its function is to provide service and protection for individual rights. The good governance principles are used a guideline for the government in in carrying out its function and duties as juridical corridor. In addition, local government is required to make public service management based on the priciples of public service as follows:

- Public Service;

- Management of Community Complaints;

- Information Management;

- Internal Supervision;

- Public Education;

- Consultation Management;

- Other public service that in line with the rule. ${ }^{11}$.

People's participation in implementing government's program must be from the beginning to the end, from the planning to evaluation step. However people's assessment on certain program become the success criteria of some program carried out by the government. A country that implements regional autonomy requires active participation in every scope of government programs. Their participation can be started from the very beginning process of a work-program carried out by the regional government.

As a holder of regional autonomy, Indonesia need people's active participation in implementing government's program. There should be a rule as juridical base to arrange their participation. Moreover Indonesia as both democracy country and regional autonomy has basic principle: government should be held from people by people and to people. It will be uncommon if the people are neglected in law formulation as they have central position in democracy.

Sherry Arnstein mentions eight rungs on the ladder of citizen participation

- Citizen Control;

- Delegated Power;

- Partnership;

- Placation;

- Consultation;

- Informing;

- Theraphy;

- Manipulation. ${ }^{12}$.

Wilcox in Purwanto also proposes a five-rung ladder of participation which relate to the stance an organisation promoting participation may take as follows:

- Information;

- Consultation;

\footnotetext{
${ }^{10}$ Hotma P. Sibuea, Asas negara hukum, Peraturan Kebijakan Dan Asas Asas Umum Pemerintahan Yang Baik, penerbit Erlangga, Jakarta, 2010, hal. 158

1 H. Andi Pangerang Moenta,Prof. H. Syafaat Anugrah Pradana, SH. MH. Pokok-pokok Hukum Pemerintahan Daerah, Rajawali pers, Depok ,2017,hal. 167

${ }_{12}$ Rival G. Ahmad dkk, dari Parlemen ke ruang Publik: menggagas penyusunan kebijakan Partisipatif, Jurnal hukum Jentera Edisi ke 2, PSHK, Jakarta, 2003, hal.109
} 
- Deciding together;

- Acting together;

- Supporting independent community interest. ${ }^{13}$

As a democaratic country, people's participation in the regional regulation become a must. It cannot be said as a democracy if they are not involved in the development process. Local government encourage people's participation the following ways:

- The regional government conveys information to public about the administration of regional government;

- The regional government encourages the society to give their support in the administration of local government;

- Local government should develop some institution and make some mechanisms that enable the societys' organizations to be involved effectively;

- Other activities should be accordance with statutory provisions. ${ }^{14}$

People's participation in development process from the beginning is one of cencrete implementation of democratic country. Because Indonesia is a law-country, juridical foundation is made as a guideline. In law's formulation process, people must have been involved so the program recomended by the excutive will be in line with people's hope. In the mandate of Law article 35 number 12 of 2011 states that the regional regulations is made on the basis of the following:

- Higher instruction of Rules;

- Regional development plan;

- Implementation of regional autonomy and duty of assistance;

- Aspirations of local communities.

Real manifestation of citizens' involvement in regional government as follows:

- Preparation of regional policies and regulations that regulate and burden the community;

- Planning, budgeting, implementing, monitoring and evaluating a regional development;

- Management of regional assets or its natural resources;

- Public-service implementation. ${ }^{15}$

While there us another legislation mentioned about citizens' participation can be in form of the following: Public Consultation; Conference; Partnership; Aspirations Giving; Supervision; Other's involvement based on the law. ${ }^{16}$

Although it has been stated in the upper level of law about people's participation in the process of formulating local government regulation, but in the real implementation it often neglects that participation.

People's participation in the process of formulating local government regulation should be in public hearing. Public hearing is an open gathering of officials and citizens, in which citizens are permitted to offer comments, but officials are not obliged to act on them or, typically, even to respond publicly. Their comments on a certain regional regulation cannot be directly included in the existing regulation but it should be included in the following draft.

Even there is an impression that public hearing is merely a formal precondition that does not have substatntive meaning to the current problem. Sometimes people who are invited in public hearing season are those who do not know exactly of the occured problem or in other word it can be said that people who attend public hearing are those who can be conditioned. While the marginal groups do not access to central governor because of their lack of human resources, as shown from their education level. The lower of education level affect on their curiosity and caring for the political and constitutional coditions in their region although it is actually related to their own rights.

\footnotetext{
${ }^{13}$ Erwan Agus Purwanto, Pelayanan Publik Partisipatif, dalam Agus Dwiyanto, mewujudkan Good Governance, Gajah Mada, Yogyakarta. 2005, hal. 192

${ }_{14}$ H. Andi Pangerang Moenta, H. Syafaat Anugrah Pradana, SH. MH. Pokok-pokok Hukum Pemerintahan Daerah, Rajawali pers, Depok ,2017,h. 171 .

${ }_{10}^{15}$ Ibid hal 172

${ }^{16}$ Undang-undang nomor 23 tahun 2014 tentang pemerintahan daerah, pasal 354
} 
A product of law of one region tend to be detrimental for other region in the nearest border administrative territories. It happens because of different natural resources although those region have a same ethnic and cultural background.

The implementation of regional autonomy has enormous power during the reformation era. Whereas in New Order Government, it was only limited to theory. Its implementation was still centralistic, means that the regional government did not have an authority to manage their own regions but they were simply restrained by central government.

Regional autonomy gives wide chances for regional government to manage and to develop their regions by optimizing their all natural resources. An area with a rich natural resources and a high human resources will lead it to be prosperous. To develop an area, it is needed the readiness of all parties including the creation of a juridical basis as a guideline for every work plan. Thus the formulation of juridical basis needs society's involvement because they know what they want. Moreover they will become the government's partner to develop the area.

A concrete evidence of the lack of people's involvement in the process of formulating juridical foundation can be seen in the Sumenep regency regulation number 13 of 2003 about mining business licenses for mining area $\mathrm{C}$. That legal product is useless for the Sumenep people which mostly working in mining business.

Illegal mining in Sumenep regency is one example of no people's participation on formulating regional regulation number 13 of 2003. They do not have any licences for mining is not because of their unawareness of the law but because they do not know exactly that Sumenenep has been have a rule about mining licence.

Illegal mining gave negative effect on environmental and social so in the process of making mining licence, it is important for the society to be actively particapated. Beside that, the implementation of democracy, goverment from people, by people and to people also need people's participation to make their hopes come true.

There were some parties who have been involved in the process of formulating regional regulation such as Regent or Mayor, Governor, Ministry of Home Affairs as executive member and Assembly at provincial and Assembly at regional as legislative member. Both legislative and executive are institutions that have authority to make and to ratify both proviancial and regional in accordance with their jurisdiction.

Their authority should not implement as they want but they should have responsible for it. Regent or Mayor, Governor, Ministry of Home Affairs or Representative Council must be responsible for the people in their own administrative area and for the official above them. Every authorized official is work in a team, as in formulating regional regulation, executive and legislative members work and discuss together to reach an agreement.

Actually a concept of law enforcement begins when a law has been made. A law enforcement is a process to legalize the law. In formulating the law, many ideas come from the legislators ${ }^{17}$. In other word, it can be said that the success or the failure law implementation depend on adequate facilities and infrastructure. Moreover, in the process of becoming a modern state, the law's role is a means of implementing government decisions.

The characteristics of law enforcement in modern state include:

- Having environmental awareness. It means that law enforcement should be related to any matters that occur in society;

- Recognizing the position and qualifications of an agency that can create better changes;

- Law enforcement will be focused on decision-making issues that just being an executing agency. ${ }^{18}$

From the description above, the writer saw a relation between law enforcement and the process of formulating that law. If there are some problems in the formulating process, it can be ascertained that the implementation of these law will also be problematic. If those cases happen, the implicit messages of the law will not be conveyed to the people.

\footnotetext{
${ }_{18}^{17}$ Satjipto Rahardjo, Penegakan Hukum ( suatu tinjauan sosiologis ), Genta Publishing, Yogyakarta, 2009,hal. 24

${ }^{18}$ Ibid, h. 140
} 
In reform era, regulation has double meaning. On one hand, it is seen as a logical result of the implementation of regional autonomy which aimed to prosper the society while on another hand they are arranged precisely to increase regionel income by neglecting the society. ${ }^{19}$

These following steps can be taken by the authorities in making local regulations:

- The law should be supervised but do not reduce its values about the basics of decentralization and local benchmark;

- They should avoid the dominance of political considerations rather than juridical and social considerations in reviewing regional regulations;

- They should avoid conflicts among central government when they examine regional regulation if its contents against the central and regional authorities;

- They should make a rule about citizens' participation in the process of formulating regional regulation. The citizens'rights to supervise and void the regulation should be mentioned in the rule;

- In formulating the legal regulation, it should be mentioned that the regulation is voidable if it neglects citizens' participation.

In Indonesia, law and politic seems to be two currencies which are inseparable and both influence each other. While in law-theory, law should come first before politic. Actually policians must obey the rule that they have made. But in a real implementation, we can see that legal products are not separated from political contracts that they have made. In a Rechtstaats, every program must have juridical foundation. Moreover Indonesia adheres Trias Politica's theory about the divison of government power from Mostesqiu, namely: Legislative, Executive and Judiciary. They actually have different duties and authorities but they are inseparable. Legislative members are people's representative elected by voters to participate in government program to represent their hope and to formulate legal product from the central government to local government. Finally the legal products that have been made by Legislative will be used as a guide for Executive members.

\section{CONCLUSION}

Based on the literature review and the result of discussion above, neglecting citizen's participation in the process of formulating a regulation raise some problems. People tend to be uncare to the law because they have not taken part in formulation process, not to disobey the law. Their participation from the beginning to the end give beneficial contribution to the regional government so the law can be implemented as their hope. As a holder of regional autonomy, Indonesia need people's active participation in implementing government's program. There should be a rule as juridical base to arrange their participation. Moreover Indonesia as both democracy country and regional autonomy has basic principle: government should be held from people by people and to people. It will be uncommon if the people are neglected in law formulation as they have central position in democracy.

\section{REFERENCES}

1. Political Science Association of Indonesia, decentralization and regional autonomy, LIPI Press, Jakarta, in 2007.

2. Bambang Waluyo, law enforcement in Indonesia, Sinar Grafika, 2016.

3. Erwan Agus Purwanto, Public Service Participatory, in Agus Dwiyanto, realize Good Governance, Gajah Mada. 2005.

4. Hotma P. Sibuea, principle of state of law, Regulatory Policy and Principle of Good Governance Principles, the publisher grants, Jakarta, 2010.

5. H. Andi Pangerang Moenta, Prof. H. Intercession Anugrah Pradana, SH. MH. Principles of the Law of Local Government, Rajawali press, Depok, 2017.

\footnotetext{
19. Leo Agustino, Politik Lokal dan Otonomi Daerah,ALFABETA, Bandung, 2014, hal. 251
} 
6. Ilham Yuli Isdiyanto, Reconstruction Law and the constitutional Indonesia, UII Press, 2017.

7. Khasan Effendy, Integrating Qualitative Quantitative Methods, Indra Prahasta, Bandung 2010.

8. Leo Agustino, Local Politics and Autonomy, Alfabeta, Bandung, 2014.

9. Rival G. Ahmad et al, from the Parliament to the public space: initiated participatory policymaking, law journal Insight Edition 2, PSHK, Jakarta, in 2003.

10. Satjipto Rahardjo, Law Enforcement (a review of sociological), Genta Publishing, Yogyakarta, 2009.

11. Sirajuddin, students sukriono and Winardi, Public Service law based on participation and openness of information, equivalent Press (group Instrans Publishing), Malang 2011.

12. Soerjono Soekanto, Factors Affecting Law Enforcement, Eagle Press, Jakarta, 2004. Inspire Bisri, the Indonesian Legal System: Principles and Implementation of the Law in Indonesia, Rajawali Press, Jakarta, in 2012.

13. Soetandyo Wignjosoebroto, Legal Paradigm, Method and dynamics problem, the Institute for Policy Research and Advocacy, Jakarta, in 2002.

14. Electronic Source: http://hukum-on.blogspot.com/2012/06/asas-hukum.html

15. Law No. 23 of 2014 on local government. 